\title{
PENERAPAN MODEL PEMBELAJARAN COOPERATIVE SCRIPT MENGGUNAKAN MEDIA GAMBAR UNTUK MENINGKATKAN HASIL BELAJAR IPS SISWA KELAS IV SD N 1 SEKARTAJI
}

\author{
I Made Astra Winaya ${ }^{1)}$ \\ Program Studi Pendidikan Guru Sekolah Dasar, FKIP, Universitas Dwijendra \\ winaya@undwi.a.id \\ I Made Sumitra Jaya ${ }^{2)}$ \\ Program Studi Pendidikan Guru Sekolah Dasar, FKIP, Universitas Dwijendra \\ Sumitrajaya90@gmail.com
}

\begin{abstract}
ABSTRAK
Penelitian ini bertujuan untuk meningkatkan hasil belajar IPS menggunakan strategi pembelajaran cooperative script pada kelas IV SD Negeri 1 Sekartaji. Jenis penelitian ini adalah penelitian tindakan kelas. Sampel pada penelitian ini adalah siswa kelas IV SD Negeri 1 Sekartaji yang berjumlah 20 siswa, terdiri dari 12 orang siswa laki-laki dan 8 orang siswa perempuan. Pelaksanaan penelitian ini dilakukan dalam 2 siklus, dengan masing-masing siklus terdiri dari dua pertemuan. Pada setiap siklus terdapat kegiatan perencanaan, pelaksanaan, observasi/evaluasi dan refleksi. Teknik pengumpulan data menggunakan observasi dan tes hasil belajar, adapun instrumen pengumpulan data menggunakan lembar hasil belajar. Teknik analisis data yang digunakan dalam penelitian ini adalah deskripsi kualitatif dan deskripsi kuantitatif. Indikator keberhasilan penelitian ini ditandai dengan meningkatnya hasil belajar IPS yakni $80 \%$ dari jumlah siswa yang mengikuti proses pembelajaran telah memenuhi Kriteria Ketuntasan Minimal (KKM) yaitu 85. Hasil penelitian ini menunjukkan adanya peningkatan hasil belajar IPS dengan menggunakan strategi pembelajaran cooperaqtive script berbantuan media gambar pada setiap siklusnya. Siklus I siswa yang mencapai ketuntasan sebanyak 5 siswa (25\%) dan belum tuntas sebanyak 15 siswa (75\%) di lanjutkan ke siklus II, jumah siswa yang tuntas belajar sebanyak 18 siswa (80\%).
\end{abstract}

Kata kunci: Cooperative Script, Media Gambar, Hasil Belajar IPS.

\begin{abstract}
This study aims to improve the learning outcomes of IPS using cooperative script learning strategies in gardes IV SD Negeri 1 Sekartaji. This tipe of research is classroom action research. The sample in this study was students from grade IV SD Negeri 1 Sekartaji, amounting to 20 students, consisting of 12 male students and 8 female students. The implementation of this research was carried out in 2 cycles with each cycle consisting of 2 meetings, in each cycle there was an implementation planning activity observation/evaluation and reflection. Data collection techniques using observation and learning outcomes test, while the data collection instruments use learning outcomes sheets. Data analysis techniques used in this study are descriptive descriptions and quantitative descrivtions. Indicaor the success of this study was marked by the increase in IPS learning outcomes, namely $80 \%$ of the number of students who took part in the learning process had met the minimum completeness criteria of KKM which was 85 results of this study showed an increase in ips learning outcomes by using a strategy cooperative script learning with images media assistance in each cycle. Cycle 1 students who achieved completeness were 5 students $25 \%$ and not yet complete 15 students $75 \%$ followed by cycle 2 . The number of students who completed study was 18 students $80 \%$
\end{abstract}

Keywords: cooperative script learning models, media images. IPS learning outcomes

\section{PENDAHULUAN}

Dalam masyarakat yang majemuk, ditingkat lokal, nasional dan global. (Catharina Tri Anni,
2009: 105) Sebagian siswa menganggap mata pelajaran IPS sebagai mata pelajaran yang sulit dipahami sehingga siswa merasa bosan, jenuh dan 
malas untuk belajar, siswa kurang termotivasi karena menganggap mata pelajaran IPS merupakan mata pelajaran yang membutuhkan pemahaman konsep yang luas, bahwa IPS merupakan disiplin ilmu sosial yang tidak terpisah-pisah. (Umaedi, 2009: 64). Aktivitas siswa yang rendah tersebut dapat mempengaruhi hasil belajar siswa, kendala-kendala yang dihadapi yaitu: (1) Siswa belum terbiasa dengan proses pembelajaran yang diterapkan oleh guru sehingga terlihat masih banyak siswa yang bingung pada saat guru mengajak siswa membentuk kelompok.( 2) Siswa belum terbiasa bertanya kepada temannya mengenai kesuliatan yang dialaminya dalam pembelajaran, (3) Dalam kegiatan demontrasi dan membacakan hasil diskusi salah satu kelompok yang ditunjuk, keaktifan siswa masih rendah,

Untuk meningkatkan hasil belajar siswa menuju peningkatan mutu pendidikan diperlukan strategi serta progam pembelajaran yang lebih efektif dan efisien, serta termasuk di dalamnya sarana, prasarana belajar guna menunjang proses yang positif terhadap hasil belajar siswa. Media pembelajaran merupakan bagian dari proses pembelajaran, oleh sebab itu dalam pemilihan media harus melihat semua komponen dari perencanaan pembelajaran seperti tujuan, materi, pendekatan, dan metode, serta bentuk evaluasi termasuk tingkat perkembangan intelektual siswa (Umaedi, 2009: 45). Mengubah pembelajaran paradigma lama yang berpusat pada guru (teacher centered) menjadi berpusat pada siswa (student centered). Menurut Umaedi (2009: 52), pemakaian media pada proses belajar mengajar sangat membantu siswa dalam memahami pesan dan informasi dari guru. Siswa akan lebih mudah membangun pemahaman melalui interaksi terhadap lingkungan sosialnya. Interaksi dapat ditingkatkan dengan belajar kelompok maupun diskusi. Penyampaian gagasan oleh siswa dapat mempertajam, memperdalam, memantapkan, atau menyempurnakan gagasan itu karena memperoleh tanggapan dari siswa lain atau guru.

Proses pembelajaran akan lebih bermakna karena siswa dapat bersosialisasi, menghargai perbedaan (pendapat, sikap, kemampuan, prestasi) dan berlatih bekerjasama. Menurut Vernon Magnesen (Catharina Tri Anni, 2009: 125) dalam penelitiannya mengenai ingatan yang diperoleh dalam belajar menyatakan bahwa kita belajar hanya $10 \%$ dari apa yang kita baca, $20 \%$ dari apa yang kita dengar, $30 \%$ dari apa yang kita lihat, 50\% dari apa yang kita lihat dan dengar, $70 \%$ dari apa yang kita katakan, dan $90 \%$ dari apa yang kita katakan dan lakukan. Dari penelitian itu tampak bahwa belajar yang baik mempersyaratkan penggabungan antara indera visual, auditori, dan kinestika. Hal ini menunjukkan bahwa jika guru mengajar dengan banyak berceramah, maka tingkat pemahaman yang diperoleh siswa hanya $20 \%$. Tetapi sebaliknya, jika siswa diminta untuk melakukan sesuatu sambil melaporkannya, maka tingkat pemahaman siswa dapat mencapai sekitar $90 \%$. Dengan demikian kualitas pembelajaran akan meningkat yang berorientasi pada peningkatan hasil belajar siswa. Hasil observasi awal mengacu 
pada hasil pencapaian pada semester dua di kelas IV SD Negeri 1 Sekartaji menunjukkan bahwa kurang efektifnya pembelajaran IPS, ini dilihat dari hasil tes formatif siswa kurang mencapai hasil yang optimal, belum mencapai KKM 85. Hasil ditunjukkan dengan pencapaian nilai terendah 65,26 dan nilai tertinggi 85,16 dengan rata-rata nilai 85 . Data yang diperoleh dari 20 siswa kelas IV ternyata hanya 2 siswa yang tuntas atau 20\%, sedangkan 18 siswa lainnya atau $80 \%$ masih belum tuntas sehingga nilai ketuntasan klasikalnya masih rendah sehingga perlu untuk ditingkatkan. Berdasarkan data hasil observasi di atas peneliti memandang masalah tersebut merupakan masalah yang segera untuk dipecahkan karena jika tidak akan mempengaruhi pengetahuan siswa dalam menerima pembelajaran berikutnya.

Untuk itu perlu dikembangkan strategi pembelajaran yang tepat, menarik dan efektif sehingga dapat meningkatkan keterampilan guru, aktivitas siswa serta hasil belajar siswa. Salah satu strategi pembelajaran yang dapat dijadikan alternative yaitu metoda pembelajaran cooperative script .berbantuan media gambar. Pembelajaran cooperative script berbantuan mmedia gambar merupakan sistem pembelajaran yang dapat membantu membangun kepercayaan diri terhadap kemampuan berfikir kritis bekerjasama dengan kelompok dalam tugas yang diberikan oleh guru dalam memahami konsep IPS (lie, 2009:12) Keunggulan dari pembelajaran ini adalah siswa dapat bekerja sendiri, menstimulus kemampuan peserta didik untuk mengajarkan kepada temannya dan kemampuan untuk menguasai sebuah topik pembelajaran. Menurut Hisyam Zaini dkk (2009: 65) strategi pembelajaran yang paling baik adalah dengan mengajarkan kepada orang lain, maka strategi ini akan sangat membantu peserta didik dalam mengajarkan materi kepada teman-temannya. Pembelajaran strategi Cooperative script merupakan refleksi pentingnya guru mengelola proses pembelajaran yang bermakna sehingga siswa merasa senang dan antusias dalam proses pembelajaran. Dalam strategi ini kemampuan siswa untuk menguasai suatu topik dengan berfikir kritis sehingga dapat menyampaikan topic yang telah dikuasai kepada teman-temannya dengan berbagai cara dan menggunakan alat peraga juga contoh-contoh relevan.

Pembelajaran Cooperative script merupakan salah satu model pembelajaran kooperatif. Kelebihan model pembelajaran Cooperative script adalah: 1) melatih pendengaran, ketelitian atau kecermatan, 2) setiap siswa mendapat peran, dan 3) melatih mengungkapkan kesalahan orang lain dengan lisan (Hamdani, 2011). Model ini juga memungkinkan interaksi di antara siswa, siswa dengan lingkungannya sebagai individu, anggota keluarga, dan sebagai anggota masyarakat dalam kehidupan yang lebih luas (Schank \& Abel-son, 1977). Langkah-langkah dalam pembelajaran Cooperative script sebagai berikut: 1) guru membagi siswa untuk berpasangan, 2) guru membagikan wacana/materi tiap siswa untuk dibaca dan membuat ringkasannya, 3) guru dan 
siswa menetapkan siapa yang pertama berperan sebagai pembicara dan siapa yang berperan sebagai pendengar, 4) pembicara membacakan ringkasannya selengkap mungkin, dengan memasukan ide-ide pokok dalam ringkasannya, sementara pendengar menyimak/mengoreksi/menunjukkan ide-ide pokok yang kurang lengkap dan membantu mengingat/menghafal ide-ide pokok dengan menghubungkan materi sebelumnya atau dengan materi lainnya, 5) bertukar peran, semula sebagai pembicara ditukar menjadi pendengar dan sebaliknya, 6) guru membantu siswa menyusun simpulan (Dansereau, 1987).

Menurut Djamarah dalam Winaya 2016 menjelaskan hasil kegiatan pembelajran tercermin dari perubahan perilaku material-substansial, struktur fungsional, maupun secara behavior. Untuk itu, guru hendaknya selalu mengukur ketercapain dari sebuah proses pembelajaran yang hasil yang diperoleh dari penilaian dinyatakan dalam bentuk hasil belajar. Tindakan atau kegiatan yang dilakukan tersebut dinamakan penilaian hasil belajar (Sukardi, 2010). Taksonomi Bloom untuk dimensi kognitif telah direvisi menjadi: mengingat, memahami, menerapkan, menganalisis, mengevaluasi, dan mengkreasi. Taksonomi Bloom yang baru ini menunjukkan bahwa: pengetahuan (knowledge) mencakup mengingat dan memahami; keterampilan (skill) mencakup menerapkan; kemampuan (ability) mencakup mengevaluasi dan mengkreasi (Krathwohl, 2002).
Dari uraian tersebut di atas maka peneliti akan mengkaji melalui penelitian tindakan kelas dengan judul: "Penerapan Model Pembelajaran Cooperative Script Menggunakan Media Gambar Untuk Meningkatkan Hasil Belajar IPS Siswa Kelas IV SD Negeri 1 Sekartaji. Adapun tujuan dari penelitian ini sebagai berikut. (1) Untuk mengetahui hasil belajar siswa dalam mengikuti pembelajaran cooperative script menggunakan media gambar untuk meningkatkan hasil belajar siswa kelas IV SD N 1 Sekartaji. (2) Untuk mengetahui kendala-kendala yang dihadapi dalam penerapan model pembelajaran cooperative script menggunakan media gambar untuk meningkatkan hasil belajar siswa kelas IV SD N 1 Sekartaji.

\section{METODE PENELITIAN}

Jenis penelitian ini adalah Penelitian Tindakan Kelas (PTK). PTK merupakan suatu pencermatan terhadap kegiatan belajar berupa sebuah tindakan, yang sengaja dimunculkan dan terjadi dalam sebuah kelas secara bersama (Suharsimi Arikunto, 2009: 3). Suharsimi Arikunto, dkk (2009: 57) dalam buku yang sama juga mengemukakan bahwa PTK adalah penelitian yang dilakukan oleh guru bekerja sama dengan peneliti (dilakukan oleh guru sendiri yang bertindak sebagai peneliti) di kelas atau di sekolah tempat ia mengajar dengan penekanan pada penyempurnaan atau peningkatan proses dan praktik pembelajaran. Tujuan dari penelitian ini adalah untuk perbaikan, peningkatan pembelajaran secara berkesinambungan dan pengembangan kemampuan serta keterampilan 
untuk menghadapi permasalahan aktual pembelajaran di kelas.

Penelitian ini dilakukan di SD Negeri 1 Sekartaji yang beralamat desa Sekartaji, Klungkung. Subjek penelitian ini adalah siswa kelas IV (empat) tahun pelajaran SD Negeri 1 Sekartaji, Klungkung yang berjumlah 20 siswa yang terdiri dari 12 siswa laki-laki dan 8 siswa perempuan. Objek penelitian ini adalah hasil belajar. Model penelitian tindakan kelas menggunakan model Kemmis dan Mc.Taggart, karena mudah dipahami dan dilaksanakan. Menurut Suharsimi Arikunto (2009: 16-19), bahwa model Kemmis dan Mc Taggart terdiri atas empat tahap, yaitu.
Siklus I

Siklus II

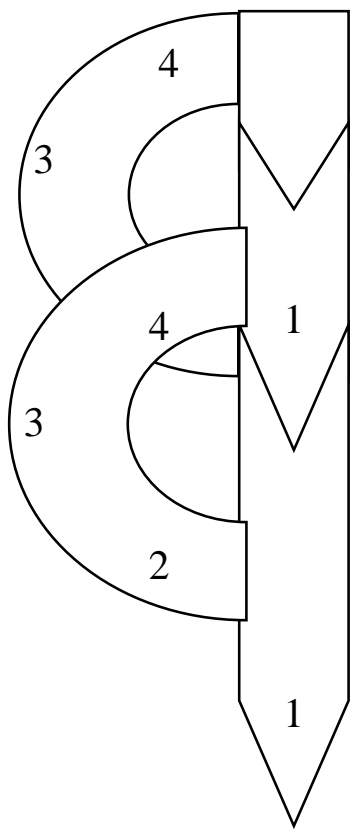

\section{Keterangan:}

\section{Siklus I}

$1=$ perencanaan $\mathrm{I}$

$2=$ tindakan I

3 = observasi I

$4=$ refleksi I

\section{Siklus II}

1 = revisi rencana I dan perencanaan II

$2=$ tindakan II

3 = observasi II

$4=$ refleksi II

\section{Gambar Model Penelitian Kemmis dan MC.Taggart (Suharsimi Arikunto, 2009: 106)}

Kemmis dan Mc. Taggart (Suharsimi Arikunto, 2009: 84) memandang komponen sebagai langkah dalam siklus, sehingga ia menyatukan komponen tindakan (acting) dan pengamatan (observing) sebagai satu kesatuan. Hasil dari pengamatan kemudian dijadikan dasar sebagai langkah berikutnya, yaitu refleksi. Penelitian ini dilakukan dalam bentuk siklus.
Setiap siklus terdiri dari perencanaan, pelaksanaan tindakan, observasi, dan refleksi. Langkahlangkah setiap siklus dalam penelitian ini adalah:

\section{a) Perencanaan}

Menelaah indikator serta materi pembelajaran IPS tentang materi Hubungan Kenampakan Alam Sosial dan Budaya dengan Gejalanya kemudian menyusun RPP sesuai 
indikator yang telah ditetapkan dan menggunakan metoda pembelajaran cooperative script berbantuan media gambar. Setelah itu menyiapkan media pembelajaran, menyiapkan alat evaluasi berupa tes tertulis, LKS dan menyiapkan lembar pengamatan (observasi) untuk mengamati keterampilan aktivitas siswa.

\section{b) Pelaksanaan Tindakan}

Pelaksanaan tindakan merupakan implementasi atau penerapan rancangan yang telah ditetapkan yaitu mengenai tindakan kelas (Arikunto, 2009:18). Dalam pelaksanaan PTK ini direncanakan melalui siklus pertama. Dalam siklus pertama dilakukan tindakan yang diwujudkan dalam skenario pembelajaran. Satu kali pertemuan yaitu 2 × 35 menit, dimana setiap pertemuan dalam menerapkan model pembelajaran cooperative script. Siklus pertama yaitu dengan materi: Hubungan Kenampakan Alam, Sosial dan Budaya Dengan Gejalanya.

\section{c) Observasi}

Observasi adalah kegiatan pengamatan yang dilakukan oleh pengamat (Arikunto, 2009: 19). Kegiatan observasi dilaksanakan secara kolaboratif dengan pengamat untuk mengamati keterampilan aktivitas siswa dengan implementasi strategi cooperative script dalam meningkatkan hasil belajar IPS siswa kelas IV SD Negeri 1 Sekartaji.

\section{d) Refleksi}

Refleksi dimaksudkan untuk mengkaji secara menyeluruh tindakan yang telah dilakukan berdasarkan data yang telah terkumpul saat proses observasi, kemudian dilakukan evaluasi guna menyempurnakan tindakan berikutnya. Refleksi merupakan kegiatan untuk mengemukakan kembali apa yang sudah terjadi dan sudah dilakukan (Arikunto, 2009: 19). Setelah mengkaji proses pembelajaran yaitu aktivitas siswa, serta pemahaman terhadap pembelajaran, apakah sudah efektif dengan melihat ketercapaian dalam indikator kinerja pada siklus pertama, serta mengkaji kekurangan dan membuat daftar permasalahan yang muncul dalam pelaksanaan siklus pertama, kemudian peneliti membuat perencanaan tindak lanjut untuk siklus berikutnya.

Dalam penelitian ini data yang dikumpulkan adalah data hasil belajar siswa kelas IV SD Negeri 1 Sekartaji dengan cara pemberian tes hasil belajar kepada masing-masing siswa, dimana tes yang digunakan adalah tes tulis dalam bentuk soal objektif sebanyak 20 soal. Analisis data yang digunakan dalam penelitian ini adalah analisis statistik deskriptif kuantitatif dengan menghitung : Skor individu, Mean( rata-rata), $\mathrm{M}(\%)$ dan ketuntasan klasikal dalam setiap siklus.

\section{HASIL PENELITIAN}

Penelitian ini bertujuan untuk meningkatkan hasil belajar IPS dengan menggunakan strategi pembelajaran cooperative script berbantuan media gambar pada siswa kelas IV SD Negeri 1 Sekartaji. Dari analisis yang telah dilakukan ternyata hipotesis yang diajukan dalam penelitian ini telah terbukti bahwa strategi pembelajaran cooperative script berbantuan media gambar dapat meningkatkan hasil belajar IPS siswa kelas IV SD Negeri 1 Sekartaji pada tahun pelajaran 2018/2019. Sebagai gambarannya. 
Pada kondisi awal menunjukkan hasil belajar siswa dari rata-rata pratindakan sebesar 65,26. Siswa yang belum tuntas sebanyak 18 siswa atau $80 \%$ dan siswa yang sudah tuntas sebanyak 2 siswa atau $20 \%$. Nilai siswa tertinggi adalah 85,45 dan nilai siswa terendah adalah 61,35. Untuk itu perlu adanya tindakan untuk mengoptimalkan hasil belajar IPS di SD Negeri 1 Sekartaji.

Adapun solusi yang dibawakan dalam penelitin ini adalah penerapan model pembelajaran cooperative script berbantuan media gambar untuk meningkatkan hasil belajar siswa kelas IV SD N 1 Sekartaji, penelitian ini dilaksanakan sebanyak II Siklus. Pada siklus I dilaksanakan dalam dua kali pertemuan. Hasil pelaksanaan siklus I menunjukkan adanya peningkatan hasil belajar kognitif siswa. Skor rata-rata hasil belajar IPS siswa pada siklus I adalah 77,18 . Nilai tertinggi adalah 86,35 dan nilai terendah adalah 75,25. Sedangkan Hasil pengamatan aktivitas siswa pada siklus I dalam pembelajaran IPS dengan Strategi pembelajaran cooperative script berbantuan media gambar menunjukkan bahwa aktivitas siswa dalam pembelajaran cukup. Dalam pengamatan aktivitas siswa ada 7 aspek yang diamati yaitu: (1) antusias mengikuti pembelajaran, (2) siswa aktif bertanya, (3) siswa aktif menjawab pertanyaan, (4) siswa aktif dalam kerja kelompok, (5) siswa mengerjakan tugas kelompok atau LKS, (6) siswa atau kelompok menyampaikan hasil diskusi, (7) memiliki perasaan gembira dalam pembelajaran.
Dilihat dari ketuntasan belajar siswa yang mengacu pada KKM dari 20 siswa, 18 siswa dinyatakan tuntas dan 2 siswa belum tuntas. Data siklus I, membuktikan sudah ada peningkatan hasil belajar IPS siswa yang mencapai KKM sebanyak $80 \%$ dari kondisi awal sebesar $20 \%$. Peningkatan hasil belajar kognitif IPS ini diperoleh dengan strategi pembelajaran cooperative script berbantuan media gambar yang diterapkan dalam proses pembelajaran, sehingga siswa termotivasi untuk belajar dan meningkatkan hasil belajar siswa. Pada siklus II dilakukan dalam dua kali pertemuan. Pada siklus II, perubahan data yang diperoleh menunjukkan ratarata hasil belajar IPS 85,16. Siswa yang dinyatakan tuntas kognitifnya sebanyak 18 siswa dan 2 siswa belum tuntas. Sedangkan untuk hasil pengamatan aktivitas siswa pada siklus II dalam pembelajaran sudah baik, hasil pengamatan aktivitas siswa yaitu: (1) antusias mengikuti pembelajaran, (2) siswa aktif bertanya, (3) siswa aktif menjawab pertanyaan, (4) siswa aktif dalam kerja kelompok, (5) siswa mengerjakan tugas kelompok atau LKS, (6) siswa atau kelompok menyampaikan hasil diskusi, (7) memiliki perasaan gembira dalam pembelajaran.

Berdasarkan hasil yang diperoleh, dari siklus I dan siklus II mengalami peningkatan $80 \%$ dari siklus I sebesar 25\% menjadi $80 \%$. Sedangkan bila dibandingkan dengan kondisi awal peningkatan hasil belajar yaitu presentase kondisi awal 20\% menjadi 80\%. Tindakan yang dilakukan pada siklus I dan siklus II membuktikan bahwa strategi pembelajaran cooperative script 
dapat meningkatkan hasil belajar IPS siswa kelas

IV SD Negeri 1 Sekartaji.

Pelaksanaan pembelajaran dengan strategi cooperative script berbantuan media gambar dapat meningkatkan aktivitas siswa dalam proses pembelajaran sehingga dapat meningkatkan hasil belajar IPS siswa. Terdapat beberapa faktor penyebab kesuksesan pelaksanaan model penerapan pembelajaran cooperative script berbantuan media gambar untuk meningkatkan hasil belajar siswa kelas IV SD N 1 Sekartaji adalah:

1) siswa merasa senang mengerjakan tugas kelompok karena peneliti menggunakkan media pembelajaran yang bervariasi. Pembelajaran yang di tujukan untuk mengatasi kebosanan siswa, sehingga dalam situasi belajar mengajar, siswa senantiasa menunjukkan ketekunan, serta penuh partisipasi.

2) Variasi pembelajaran dapat di kelompokkan ke dalam tiga kelompok atau komponen, yaitu: (1) Variasi dalam cara mengajar guru, meliputi: penggunaan variasi suara (teacher voice), Pemusatan perhatian siswa (focusing), kesenyapan atau kebisuan guru (teacher silence), mengadakan kontak pandang dan gerak (eye contact and movement), (2) Variasi dalam penggunaan media dan alat pengajaran. Media dan alat pengajaran bila ditunjau dari indera yang digunakan dapat digolongkan ke dalam tiga bagian, yakni dapat didengar, dilihat, dan diraba. Adapun variasi penggunaan alat antara lain adalah sebagai berikut: variasi alat atau bahan yang dapat dilihat (visual aids), variasi alat atau bahan yang dapat didengar (auditif aids), variasi alat atau bahan yang dapat diraba (motorik), dan variasi alat atau bahan yang dapat didengar, dilihat dan diraba (audio visual aids). (3) Variasi pola interaksi dan kegiatan siswa. Pola interaksi guru dengan murid dalam kegiatan pembelajaran sangat beraneka ragam coraknya. Penggunaan variasi pola interaksi dimaksudkan agar tidak menimbulkan kebosanan, kejemuan, serta untuk menghidupkan suasana kelas demi keberhasilan siswa dalam mencapai tujuan.

3) Kelebihan model pembelajaran cooperative script berbantuan media gambar adalah karena hal itu dapat memotivasi siswa untuk lebih aktif dan kreatif dalam proses pembelajaran. Strategi cooperative script berbantuan media gambar dalam pembelajaran IPS sangat mendukung dan sesuai untuk mencapai keberhasilan suatu kegiatan pembelajaran, karena implementasi strategi cooperative script berbantuan media gambar mempunyai manfaat antara lain meningkatkan partisipasi siswa, meningkatkan keberanian/ keantusiasan siswa untuk bertanya, mengungkapkan ide, gagasan, maupun pendapat, mengembangkan kreativitas siswa, meningkatkan keterampilan berfikir siswa, menciptakan suasana/ iklim yang kompetitif sehingga siswa menjadi aktif dalam pembelajaran. Maka dengan implementasi Strategi cooperative script 
berbantuan media gambar dapat memberikan pengalaman belajar yang berkesan bagi siswa, sehingga pembelajaran IPS dapat berjalan lebih bermakna dan efektif, karena media lebih bervariasi dan dapat meningkatkan keterampilan guru, aktivitas siswa serta hasil belajar siswa dalam pembelajaran IPS.

\section{KESIMPULAN}

Berdasarkan hasil penelitian dan pembahasan maka dapat disimpulkan belajar siswa mengalami peningkatan pada siklus I dan siklus II. Hasil belajar siswa dalam pembelajaran IPS menggunakan strategi cooperative script berbantuan media gambar pada siklus I diperoleh $75 \%$ (15 siswa) dalam katagori belum tuntas dan $25 \%$ (5 siswa) dalam katagori tuntas. Hasil tes pada siklus II merupakan hasil tes individu dalam pembelajaran IPS menggunakan Strategi cooperative script berbantuan media gambar. Jumlah siswa yang mengikuti tes siklus II berjumlah 20 siswa. Tes siklus II yang dilakukan adalah mengerjakan soal evaluasi dari materi hubungan kenampakan alam dan buatan dengan gejalanya. Hasil belajar siswa dalam pembelajaran IPS menggunakan strategi cooperative script berbantuan media gambar pada siklus II, diperoleh $20 \%$ (2 siswa) katagori belum tuntas dan $80 \%$ (18 siswa) dalam katagori tuntas.

Berdasarkan hasil penelitian yang diperoleh, maka peneliti dapat memberikan beberapa saran yaitu: (1) Kerjasama untuk memecahkan suatu masalah dalam materi pembelajaranakan lebih mudah jika diselesaikan secara kelompok, dan siswa harus percaya diridalam bertanya maupun menjawab pertanyaan sehingga kegiatan pembelajaran berjalan dengan aktif dan tujuan pembelajaran dapat tercapai secara optimal. (2) Strategi cooperative script berbantuan media gambar bisa digunakan sebagai salah satu alternatif strategi pembelajaran bagi siswa Sekolah Dasar, karena siswa akan menjadi aktif, inovatif, kreatif, efektif, dan senang. (3) Sekolah dapat menyediakan sarana dan prasarana untuk pengembangan pembelajaran untuk mewujudkan pembelajaran yang aktif, inovatif, kreatif, efektif dan menyenangkan.

\section{DAFTAR PUSTAKA}

Anita Lie. (2009). Cooperative Learning. Jakarta: PT Grasindo.

BSNP. (2009). Standar Isi dan Standar Kompetansi Kelulusan untuk Satuan Pendidikan Dasar SD/MI. Jakarta: Depdiknas.

Catharina Tri Anni, dkk. (2009). Psikologi Belajar. Semarang: UPT UNNES Press.

Departemen Pendidikan Nasional. (2009). Kegiatan Belajar Mengajar YangEfektif. Jakarta: Balitbang Depdiknas.

Depdiknas. (2009). Standar Kompetensi Mata Pelajaran IPS Kurikulum Berbasis Kompetensi. Jakarta: Pusat Kurikulum Balitbang, Depdiknas.

Endang Poerwanti, dkk. (2009). Asesmen Pembelajaran SD. Jakarta: Direktorat Jendral Pendidikan Tinggi Departemen Pendidikan Nasional. 
Etin Solihatin. (2009). Cooperative learning Analisa Model Pembelajaran IPS. Jakarta: Bumi Aksara.

Hidayati, dkk. (2009). Pengembangan pendidikan IPS SD. Jakarta: Depdiknas.

Hisyam Zaini, dkk. (2009). Strategi Pembelajaran Aktif. Yogyakarta: CTSD.

Kasihani Kasbolah. (2009). Penelitian Tindakan Kelas (PTK). Jakarta: Depdikbud.

Nasution. (2009). Proses Belajar Mengajar. Jakarta: Depdiknas.

Winaya, I Made Astra. 2016. "Pengaruh Model Quantum Teaching terhadap Hasil Belajar ditinjau dari Keterampilan Berpikir Kritis Siswa pada Pembelajaran IPA di Kelas V SD N. 1 Selanbawak". Jurnal Kajian Pendidikan Widya Accarya FKIP Universitas Dwijendra ISSN NO. 2085-0018 Maret 2016.

Zainal Aqib. (2009). Penelitian Tindakan Kelas. Bandung: Krama Widya. 